International Journal of Current Aspects in Finance, Banking and Accounting, Volume 3, Issue 2, 2021 PP 79-103, ISSN 2707-8035

\title{
Financing Options and Growth Rate of Real Estate Development Companies in Kenya
}

\author{
Geofrey Muturi Njoroge ${ }^{1}$, Jeremiah Koori ${ }^{2}$, Fredrick Warui ${ }^{3}$ \\ ${ }^{1}$ Student, Master of Science in Finance of Kenyatta University, Kenya \\ ${ }^{2,3}$ Accounting and Finance Department, Kenyatta University, Kenya
}

\section{ABSTRACT}

Financing decisions have been a challenge to real estate developers in Kenya. This is because, real estate investments are perceived to be capital intensive in nature. It is expected that real estate sector should develop in line with population increases which characterises most emerging economies. However, the provision of housing units per year is below the demand. In Nairobi region the demand for housing is 200,000 units per year while the actual production is estimated to be 50,000 units annually thus outlining a shortage of 150,000 units. Past studies indicate that where a robust financial market prevails, investors are able to access funds for investment projects. This current study seeks to establish the effect of financing option on real estate growth in Kenya. The specific objectives were; to determine the effect of mortgage financing on growth rate of real estate development companies in Kenya, to find out the effect of retained earnings on growth rate of real estate development companies in Kenya, to establish the effect of private equity on growth rate of real estate development companies in Kenya, to determine the effect of joint venture on growth rate of real estate development companies in Kenya and assess the moderating effect of firm size on relationship between financing options and growth rate of real estate development companies in Kenya. This study was be anchored by the following theories namely: lien theory of mortgages, pecking order theory, transaction costs theory, resource dependency theory and housing cycle theory. The target population of this study comprised of all the seventy-two companies who are members of the Kenya Property Developers Association (KPDA). The sample size comprised of twenty three companies which was thirty percent of the sample frame. The sample size was selected using simple random sampling design. This study used descriptive research design with a regression model with the regressor being real estate growth rate which was expressed in growth rates of housing units for each firm. Therefore, this study followed panel data analysis as individual firm data was collected for a time span of five years 2014 to 2018. Results showed that mortgage financing positively but insignificantly affected growth rates of real estate development companies in Kenya. Further results showed that retained earnings as source of financing option significantly impaired growth rates of real estate development companies. Private equity was found to improve growth rates of real estate development companies significantly. Joint venture too positively but insignificantly influenced growth rates of real estate development companies in Kenya. Lastly, firm size was found to be a non-moderator but rather an explanatory variable and impaired growth rates in a significant manner. This study recommended that real estate development companies should increase use of private equity in financing housing projects as this increases growth rates of the entities.

Key Words: Financing Options, Financing Structure, Real Estate Development

DOI: $10.35942 / \mathrm{ijcfa} . v 3 i 2.201$

\section{Cite this Article:}

Njoroge, G., Koori, J., \& Warui, F. (2021). Financing Options and Growth Rate of Real Estate Development Companies in Kenya. International Journal of Current Aspects in Finance, Banking and Accounting, 3(2), 79-103. https://doi.org/10.35942/ijcfa.v3i2.201 
International Journal of Current Aspects in Finance, Banking and Accounting, Volume 3, Issue 2, 2021 PP 79-103, ISSN 2707-8035

\subsection{Introduction}

In many countries, both developed and emerging economies, the real estate sector has continued to attract new investors due to what has been seen as an increase in the demand for housing units. Perhaps, this can be attributed to the rising population that is characterised by rural-urban migrations (Nguyen, Nguyen, \& Dang, 2017). In this regard it is true to suffice that the demand for houses is bound to keep on increasing with human population increase. In China, there has been what has been termed as real estate boom in which estimated 100 billions square feet of houses particularly those for residential use were built in ten years' time up to 2014 (Glaeser, Huang, Ma, \& Shleifer, 2017). This is a clear manifestation that the real estate is huge sector whose contribution to the economic development of most states cannot be overlooked. Notably, there has been speculations of the real estate being a bubble that may bust in due course of time but this is yet to happen. The growth of real estate has been steady and it is expected to remain as such in the near future half a century (Groh \& Leiser, 2014). Globally, growth of real estate sector has been viewed to be as a result of numerous factors which are firm specific, industrial factors and also macroeconomic environment of specific nations. In 2016, real estate contributed to $2.0 \%$ (2,911, 538 people) of employment in the European Union and real estate activities contributed to about $5.9 \%$ of all firms which totalled to about 1,436,433 entities in the bloc (Europen Commission, 2019).

Among the Middle East and North Africa (MENA) countries, foreign direct investments (FDI) has been noted to major strategic factors that has fostered the real estate business (Mohamed \& Baum, 2016). In the United States, real estate development recorded a hitch in which there was a fall by $3.6 \%$ of new houses starts to 1,256, 000 units and completion was low by $3.9 \%$ represented by 1.099,000 units 2018 (United States Bureau, 2019). FDI investments are an important source of capital for capital intensive projects such as those done by real estate companies. It is for this reason that those countries that are capable of attracting foreign investors, are often characterised with rise in real estate sector. In particular, foreign investors are keen to venture in commercial real estates as they stand a chance of making high returns on their investments (Cechetti \& Kharroubi, 2015). In China, the increasing prices of houses has led to the growth of the real estate as more investors channel their funds towards developing more units in order to earn more profits (Wang, Wang, Li, Zhang, \& Li, 2017). These are industrial factors which affect growth of the real estate in the Far East country. In the United States, capital development in terms of financing options has been noted to a major determinant of property levels (Mauck \& Price, 2017). Similar sentiments that the real estate flourishing in Brazil is dependent on funds availability were echoed by, (Bianco \& Yoshino, 2012). It is true to suffice that capital requirement is a huge dilemma for managers of real estate investment firms. This is because, real estate developers are involved in long term projects whose returns may take years to recoup the initial capital (Dan, Nan, \& Yuan, 2015).

Thus, there is a need for management to critically pick their preferred financing options in a way that the current and future cash flow of the firms are not compromised (Hoesli \& Reka, 2013). It is the growth of a single firm with that of another in the same sector that results to sectoral growth. Therefore, specific firms' welfare potentially contribute to the development of the entire market. Real estate development is an industry that is affected by both internal factors and external conditions of the markets. How capital is sourced, utilised in projects is an important responsibility of the management of real estate firms (Pavlov, Steiner, \& Watcher, 2015). At the regional level, real estate sector has been noted to enlarge in the last three decades. For instance, in Nigeria, financial system has been hailed as being supportive to real estate sector through establishment of arrangements such as Mortgage companies and Pension funds (Adetiloye \& Eke, 2016). In fact since most African countries are categorised as third world countries and as such, the peak of real estate development is yet to be achieved. Real estate 
International Journal of Current Aspects in Finance, Banking and Accounting, Volume 3, Issue 2, 2021 PP 79-103, ISSN 2707-8035

development in East Africa has not been good as Kenya and Tanzania faces a short fall 200, 000 and 2, 000, 000 units respectively while Uganda and Rwanda has shortage of housing units by 2.1 million units and 458,000 respectively (Anyanzwa, 2018).

\subsection{Statement of the Problem}

Real estate growth is vital to the economy of most nations because it enhances the affordability and accessibility of housing goal that is sought by governments. Over the last ten years (20092019), the number of registered real estate developers has increased by 6.3 percent with 72 fully registered firms at 2019 which is relatively higher increase compared to other countries like Uganda at 5.6 percent and Tanzania at 6.0percent. Given the high increase, the general expectation is that the number of housing units developed over the same period should increase at the same rate or surpass that rate. However, the growth rate in real estate has reported a moderate rate of 6.0 percent per annum. This is clearly below the government target of 10 percent growth rate per year which translates to 500, 000 units by 2022 in order to meet increasing demand for housing (HHK, 2019). At the national level, housing units deficit in Kenya in 2018 was about 1.9 million units and this is expected to rise to over 2.2 million units by 2022 and equally more than 60 percent of the projected 60 million people by 2030 will be living in urban areas in Kenya (Cytonn, 2019). Real estate business is one of the important pillars of economic development owing to its role in the economy (Huang \& Ma, 2015).Thus, the contribution of the real estate industry in the economy cannot be overlooked.

A number of studies have been undertaken in Kenya on various aspects of the real estate industry. Juma (2014) undertook to assess the effect of country level factors on development of real estate sector. The study revealed that exchange rates, increase in money supply, inflation rates and Gross Domestic Product positively and significantly affected growth of the sector. On the other hand Nzalu (2012) assessed the determinants of real estate growth in Kenya. The outcome was that both GDP and Inflation were significant determinants of real estate growth in Kenya. Another study was undertaken by Jumbale (2012) with the aim of determining factors influencing real estate financing. It was established that prices of houses significantly affected real estate financing. In realisation of this research gaps, current study sought to bridge the gap by assessing the effects of financing options on growth rate of real estate development in Kenya .The study specifically assessed the contribution of retained earnings, mortgage, equity and joint venture on growth of real estate sector.

\subsection{Research Objectives}

\subsubsection{General Objective}

The general objective of this study was to assess the role of financing options on growth rate of real estate development in Kenya.

\subsubsection{Specific Objectives}

These were the five specific objectives of the study:

i. To determine the effect of mortgage financing on growth rate of real estate development companies in Kenya.

ii. To find out the effect of retained earnings on growth rate of real estate development companies in Kenya.

iii. To establish the effect of private equity on growth rate of real estate development companies in Kenya.

iv. To determine the effect of joint venture on growth rate of real estate development companies in Kenya. 
International Journal of Current Aspects in Finance, Banking and Accounting, Volume 3, Issue 2, 2021 PP 79-103, ISSN 2707-8035

v. To assess the moderating effect of firm size on financing options and growth rate of real estate development companies in Kenya.

\subsection{Literature Review}

\subsection{Theoretical Literature Review}

A clear understanding of variables of a study is enhanced through selection of relevant theories. A theory provides a linked idea on why things behave or exist as they do and this reasons are based on general terms (Harasim, 2017). In this respect, a theory is basic supposition whose theme is to provide explanations on phenomenon. As such, theories can be viewed as postulates that tends to justify why things exist as they do. Theories have been viewed as seasoned reasons why things look and acts as they do. Theoretical review in research provides the background to which all constructs of knowledge about variables are based on (Grant \& Osanloo, 2016). This study seeks to examine influence of mortgage financing, retained earnings, private equity and joint venture on real estate growth rates in Kenya. These variables are backed up by lien theory of mortgage, transaction costs and resource dependency theory.

\subsubsection{Lien Theory of Mortgage}

This theory forms the basic understanding of how mortgages work. The theory owes its origin from the work of law scholar and professor (Lloyd, 1923). It posits that that there are two scenarios in the business of mortgage where there is a party that holds the title and the party that holds the lien (Harris, 2017). According to this theory lien is a right that allows one party to retain possession of an economic unit up and until the debt is fully settled. In other words, lien allows the borrower to use the asset but the ownership actually belongs to the lender. Put differently, lien is a right to reclaim the property in the event that the debtor fails to honour the financial obligation attached to the items under the contract. This theory asserts that in such an engagement as mortgage contracts, the buyer occupies the property but is not the legal owner until the final loan dues are paid as predetermined (Pancak \& Miceli, 2017). In order to remove the lien from the seller, the buyer must service the loan arrangement to the last cent without which the title remains with the lender (Abdulrehman \& Nyamute, 2018). In line with mortgage engagement, the lender issues what is known as deed of trust which is a document that officialises the mortgage arrangement. At the end of the mortgage period, a deed of conveyance is signed which shows that the lender has exonerated all rights attached to the property to the buyer.

Notably, even if the mortgagee holds the title, there is a clause that permits the seller to repossess the property should the buyer default in loan repayment (Owuor, Githii, \& Mirie, 2018). The lien theory points towards one major aspect of mortgage arrangement: that until the loan is repaid in full, the title remains the right of the mortgagor. In this regard, what the lien does it to strictly protect the interests of the lender during the mortgage period. Lien theory is pertinent to this study as it provides insights on how mortgages works. Determining the effect of mortgage financing forms part of the specific aims of this study. Lien theory views that the title rests with the party granting the mortgage until the loan is repaid. Theoretically, it is expected that a real estate company getting funding from mortgage ought to expand its operations (Tsvihum, 2014). This is because, mortgages does not necessitates the buyer to have and pay the cash price for the property but rather is granted ownership under lien. A real estate issues mortgages to buyers of land thus this may make the units being sold by the firm attractive to housing units buyers. In this respect therefore, mortgage can be hypothesised to have a positive influence on real estate growth rates. 
International Journal of Current Aspects in Finance, Banking and Accounting, Volume 3, Issue 2, 2021 PP 79-103, ISSN 2707-8035

\subsubsection{Pecking Order Theory}

Pecking order theory, owes its origin from the works of Myers and pertinently sheds light on firms' capital structure decisions (Vandana, Pramod, \& Surendra, 2016). This theory reveals that the organisations tend to utilize funds that can be obtained internally such as retained earnings by ploughing back profits before going for external financiers (Majluf \& Myers, 1984). Pecking order theory idealises and recommends that internal financial resources need to be exhausted before external funds are looked for. It was revealed that the capital structure differ among different types of firms thus making each firm to have a unique decision about the business. This indicates that once entities have used profits in furtherance of investments, then they can consider raising finances from the outside. For instance, young and small ventures may seek private equity as big corporations tends to issue equity in the public markets (Onatca, Sefika, Erbas, \& Gokhan, 2019). However, there is always a trade-off between the various sources of financing. For instance, debts results into a tax shield since interest charges on credit is tax allowable while at the same time it exposed firms to bankruptcy risks should they fail to honor the obligations (Zelia \& Caetano, 2015). Internal financing by ploughing back profits is seen as the cheapest and the best form of capital. Profits have no costs and thus do not negatively effect on the executions as they are internally generated. With aspect to the pecking order theory loans should only be sought after the retained earnings have been exhausted (Zelia \& Caetano, 2015). The issuance of shares should be the final option of raising capital since issuance of more shares leads to dilution of the ownership (Onatca, Sefika, Erbas, \& Gokhan, 2019). This theory is important to this study because of two aspects. Firstly, the theory provides a guideline on financing options that firms use in order to finance their investment activities. Retained earnings is viewed as the most accessible and affordable source of financing for firms. In the light of this observation, this theory relates with the variable whose theme is to examine the effect of retained earnings on real estate growth rate in Kenya. Secondly, pecking order proposes on debts financing when retained earnings has been exhausted before issuance of share capital is done. This postulate therefore, provides a framework of financing decisions which can reduce costs of financing and still ensure survival and growth of entities.

\subsubsection{Transaction Cost Theory}

Transaction cost economics are constructs that are used to explain the mechanisms that firms adopt in establishing strategic alliances in order to boost organisational performance. To this end, transaction cost theory seeks to theorise the basic theme of using joint ventures and private equity as fund sources which are unique to real estate developers. This theory was developed by (Williamson, 1975). According to this theory, transaction costs (TC) are those costs that are as a result of internal business processes of firms. In this respect therefore, transaction costs are different from one firm to another depending on efficiency and perhaps economies of scale (Wiesner, 2017). This proposition advocates for optimal decisions by firms in regard to loss of efficiency in which case, such firms should seek strategic partners in order to reduce such avenues of losses. Transaction cost theory relies on the idea that one can outsource and still form a competitive edge in the market, for instance due to unfailing meeting of customer satisfaction. TC is a trade-off between controls and cost sharing aspects (Bahli \& Rivard, 2017).

TC advocates of critical evaluation of the market players in order to identify potential partners that firms can form alliances with (Hajli, Shanmugam, Khani, Hajli, \& Wang, 2015). This means that where parties find a common ground to engage in economic activities, then joint ventures and private equity arrangements are established. It is the frequency of interactions and relationships that leads to formation of joint ventures and private equity arrangements (Ketokivi \& Mahoney, 2018). In other words, it is through expectations of synergies through 
International Journal of Current Aspects in Finance, Banking and Accounting, Volume 3, Issue 2, 2021 PP 79-103, ISSN 2707-8035

collaborations that establishes joint ventures. Another key ingredient of TC through joint ventures is that it permits firms to share information, managerial skills, risks and returns (Bahli \& Rivard, 2017). Due to managerial levels differences, joint ventures can help in fostering efficiency which can lead to improved performance.

In connection to this study, this TC theory is important in three folds. Foremost, the theory notes that frequent interactions between businesses players can led to formation of strategic alliances which enables returns and risk sharing. Second, TC views that joint ventures are formed by two parties who have a common economic goals, for instance, to maximise returns and cost reduction. Thirdly, this theory posits that joint venture can lead to formation of new entities which are not independent from the original companies. It is important to note that real estate developers are involved in large scale operations which may be costly and complex making it necessary to form joint ventures. Accordingly therefore, this theory relates well with joint venture and private equity predictors.

\subsubsection{Resource Dependency Theory}

Organisations takes different structures and utilise varying strategies to achieve organisational goals. Resource Dependency Theory (RDT) is a proposition of how strategies and structures are selected through managerial decision or absence of it thereof. This theory owes its origin from the works of two theorists, (Salancik \& Pfeffer, 1978). The theory posits that firm's actions and inactions are dependent on resources availability. Thus this theory advocates that organisations' structures and decisions are a function of the environment, power and control concentration within the firm and power and control outside firm. (Pfeffer, 1987). In other words, the entity does not select structure by itself but rather it is influenced by environmental characteristics. A vital proposition of this theory is that it shows that organisation's actions are influenced by resources it owns. It is for this reason that it is noted that absence of resources and market for the product for the firm drives the firm out of operation to bankruptcy (Wiarda, 2018). RDT assumes that decision making in the organisations is rational and base done on a great deal of information processing (Pfeffer, 2005). In this respect, organisations can further their operations after a careful response to the uncertainty presented in the organisation. Notably, ownership of internal resources has for a long time taken the central theme of organisational wellbeing. For instance, where a real estate developer has access to vital prime land, the land becomes critical resources and the firm can have power dominance in the market. Ideally, RDT characterises an organisation as an open system whose operations can be influenced by the environmental contingencies (O'Keeffe, 2016).

A central assumption of RDT is based on the fact that the environment is characterised as being unstable and thus uncertain (Schiele, Ellis, Ebig, Henke, \& Kull, 2015). Secondly, firms interact with the environment thus open systems and thirdly, dependency on both internal processes and external environment dictates how decisions are made with the organisation after rational information processing. RDT posits that the survival of entities depends on its access to resources and maintenance of the resources (O'Keeffe, 2016). However, access to information is not always in perfect congruency to management needs thus leading to bounded rationality. Bounded rationality denotes the limitations that decision makers are put in due to complexity in information processing. Thus, processing of information is a function of cognitive skills rendering the process to have limited capabilities to reduce environmental uncertainty through information processing (Cambria, Poria, Bajpai, \& Schuller, 2016). In the context of this study, resource dependence theory is pertinent in the understanding use of varied sources of financing specific to real estate developers. Resource dependence theory idealises that physical, financial and human resources are crucial towards sustenance of productivity and growth of firms. PE funds normally make use of this theory where they set pre-condition to be 
International Journal of Current Aspects in Finance, Banking and Accounting, Volume 3, Issue 2, 2021 PP 79-103, ISSN 2707-8035

included in the board of directors to the firm in which they are to invest their funds. This helps them monitor and contribute to any board decision made in regard to the organization investment decisions.

\subsubsection{The Housing Cycle Theory}

This theory is often known as the Needleman theory as it owes it origin from the works of Needleman (1965). This theory posits that housing development tends to be cyclical in nature depending on the nature and trend of macroeconomic environments. The theory views that housing development depends on prices and vacancies (Nicolás \& Alexander, 2017). Vacancies is used to infer to the demand for houses in the entire country while prices is the exchange value for unit of houses. It is proposed that where the prices of houses are low and the demand is low, the housing sector slows thus fewer units are constructed. It is the vacancy ratio that determines the growth of housing units in a country as real estate developers will construct more houses where the demand is high (Nicolas \& Peter, 2016). More importantly, vacancy ratio is in turn influenced by other macroeconomic factors such as inflation, interest rates and disposable income. For instance, where the economy is growing and economic units have disposable income with desires to own houses, then this creates a vacancy ratio which leads to investments on housing by real estate developers. This theory denotes that housing demands, for instance due to increasing number of households, it results to a pull situation where the real estate investors builds more houses. An increasing demand for housing units leads to an increase in prices which encourages the number of real estate developers who seek to reap in the benefits of the flourishing industry (Nicolás \& Alexander, 2017).In this respect, therefore, prices increases in the real estate industry motivates investors to invest in real estate sector thus increasing the output of the entire sector.

It is true to suffice that more real estate developers will obviously increase the number of housing units in an economy thus leading to growth rates. Where prices of housing are too much, the demand will fall and this may lead to a reduction of units that real estate developers are willing to release to the market (Needleman, 1965). Buyers will for instance prefer to hold cash and perhaps buy houses when prices go down. It is this cyclical system therefore that determines the growth of real estate sector in the country. In other words, when the prices are seen as lucrative, more investors joins the sector due to the need to make profits. Thus, prices of houses stays high even when supply is high but to a certain limit when the growth starts to decline (Nicolas \& Peter, 2016). The housing cycle theory is pertinent to this study because it helps in understanding the real estate growth rates in the county. It is important to note that the real estate sector is affected by macroeconomic conditions. Changes in disposable income for corporates and households, inflation rates, interest rates, prices of houses tends to dictate the trend of housing units. This theory provides information on growth of real estate sector and takes into consideration of prices of houses and other macroeconomic variables. It is this cycle that leads to high or low growth rates of the real estate sector.

\subsection{Empirical Literature Review}

In essence, a good research should not be a duplication of what has already been done but rather should clearly identify a gap to fill. This gap could be in form of the contextual framework of the study. This section seeks to provide the empirical review whose aim is to provide the gap that is study seeks to fill. It is arranged in line with the selected predictor variables of real estate growth rates. Additionally, local and global studies are discussed.

\subsubsection{Mortgage Financing and Growth of Real Estate Development}

In China, the study on real estate boom was done by Glaeser, Huang, Ma and Shleifer (2017) where the study sought to establish the factors that contributed to the rapid growth of real estate 
International Journal of Current Aspects in Finance, Banking and Accounting, Volume 3, Issue 2, 2021 PP 79-103, ISSN 2707-8035

sector in China. The study used content analysis from data that was collected from the National Bureau of Statistics in China. It was revealed that various micro factors and macroeconomic factors contributed to the growth of real estate in China. In particular, it was noted that speculative and mortgage aspects were the major firm specific factors that fostered real estate developer's growth. On the other hand, demand for more housing units, population growth, economic development and prices for housing lead to more constructions thus leading to growth in the real estate in the Far East country.

Adetiloye and Eke (2016) examined financial architecture in real estate in Nigeria and its contribution on economic development in Sub-Saharan African countries. This study sought to describe the real estate in Nigeria, identify financing options and establish the role of real estate on economic growth. A time series analysis was done where data was collected from 1975 to 2011 from government publications. It was revealed that real estate was affected by savings rates, mortgage and capital formations. In addition, the contribution of real estate to economic growth was found to be significant as established by the Granger causality test. More so, the study found out that the financial system and access to variety of funding sources affected real estate status in Nigeria. Whilst, this study is crucial it has a wide scope making it necessary to undertake this current study. Besides, this study was done in West Africa whose financial structure may be fundamentally different from that of East Africa where Kenya is located.

In a closely similar study, a review of mortgage and its influence on performance of real estate market was done by Kioko (2014). The study had the purpose of establishing whether mortgage had effect on real estate developers in Kenya. Population of this study was thirty five mortgage dealing entities in Kenya from which a sample of three hundred and ninety two respondents were picked for data collection. In obtaining inferences, a descriptive research framework was used where first hand data was harnessed through issuance of questionnaires. The regression analysis was obtained by using SPSS. It was revealed that mortgage had a positive influence on real estate performance. This was attributed to the idea that mortgage financing facilitates home owners to acquire housing units without the total cash price of the houses. In as much this study provides information on mortgage financing, the study used primary data while this current study used secondary data and take into consideration changes in financial framework within the country.

Another study was done on the effect of mortgage finance on development of real estate in Nairobi County by, (Kitavi, 2013). The variable of the study was mortgage finance. Population of this study was comprised of twenty five mortgage service providers. The study used the descriptive resign design with inferential statistics and secondary data was collected from 2008 to 2012 from the publications of the Central Bank of Kenya. It was revealed that mortgage and housing units construction exhibited a positive relationship that was significant. This is to mean that mortgage finance fosters growth or real estate. Whilst this study provide valuable information on role of mortgage finance on growth or real estate in Kenya, the study had a single predictor and used a simple regression while this study was a panel data analysis.

\subsubsection{Retained Earnings and Growth of Real Estate Development}

Ogbenjuwa, Egbu, and Robinson (2018) examined the real estate finaincing challanges in Nigeria. In order to achieve its general purpose, the study assesed the effect of economic factors, policy requiremnts, regulatory framework and private sector developers. The study was a content analysis of published journal articles. It was revealed that economic factors such as growth of the economy, shrinking Naira value, access to bank loans, inflation rates, and ownership of internal savings were significant economic factors on real estate development in the West African country. On policy framework, it was revealed that the monetary and fiscal policies at times promoted real estates while in other times they were challenges. Their paper 
International Journal of Current Aspects in Finance, Banking and Accounting, Volume 3, Issue 2, 2021 PP 79-103, ISSN 2707-8035

concluded that both internal and external funds plays an important role on real estate wellness. This study has several shortcomings. First, it has a very wider scope and secondly, it does not use data of its own. In the light of this observation, this current study analysed data on savings from a sample of firms and determine whether internal fundings enhances real estate growth.

Mustaruddin, Zahirdin, and Octaviani (2017) assesed ownership structure and its potential effect on corporate performance of real estate firms in Indonesia. This study has the specific objectives of investigating the role of managerial ownership, insitutuonal investors and Economic Value Added on firm value. The study was a panel data of data collected from 2010 to 2015 from real estate firms that were listed on the Indonesia Stock Exchange. The study revealed that insitutional, debt and managerial ownership had negative and significant effect on real estate firms performance. On the other hand, firm size positively impacted on real estate firms. This revelations indicates that shares owned by insititutuons may not foster performance. This study is quite broad and does not focus on sublet sources of financing that are specific such as savings, venture capital, mortgage and joint ventures.

\subsubsection{Private Equity and Growth of Real Estate Development}

Dabara, Omotohinshe, Chiwuzie, and Olusula (2018) examined Real Estates Investments Trusts(REITS) among real estate develoeprs in Nigeria. The objectives of the study were to identify the usage of REITs as form of private equity in real estate ventures and connect their effect on real estate market. The study had a population of all REITs firms in Nigeria who were four. A descrptive research design was used and data was collected from 2008 to 2012. On data analysis, it was revealed that REITs in Nigeria exhibited oligopolistic structure and thus were not competitive thus did not significantly impact on growth of real estate in the country. This study is pertinent as it provides information on various forms of private equity. However, the study did not expressly seek to evaluate the extent and nature that private equity arrangements influence growth of real estate sector. Having noted this gap, this current study evaluated influence of private equity on growth of real estate in Kenya.

Kibunyi, Ndiritu, Carcel, and Alana (2017) examined the factors that influenced house prices in Nairobi. In addition, the study used causality test in order to report whether there existed a bubble in prices of houses. Predictor variables that were assessed were; Gross Domestic Product, diaspora remittances, interest rates, construction costs and loans to the real estate sector. The study revealed that Gross Domestic Product, diaspora remittances, interest rates, construction costs and loans. However, inflation was noted to have a negative impact on prices of houses. This study provides good insights on what determines prices of houses and perhaps, performance of real estate developers but does not examine the role of various financing options on growth. More so, the study did not specifically take into consideration that private equity in form of diaspora remittances and loans to the sector had potential impact on growth of real estate in Kenya. This study sought to assess the effect of private equity and growth of real estate in Kenya.

Kissi, Duodu, and Somiah (2016) undertook a study on factors influencing venture capital of real estate development in Ghana. They used the descriptive research design where first hand data was collected. Questionnaires were used to collect data from a sample of respondents who were picked from the Ghana Real Estate Developers Association (GREDA). It was revealed that there were various factors that affected real estate venture capital which were firm based and others were market based. Particularly, they revealed that venture capital was greatly affected by high interest rates, lack of collaterals, inadequacy of records and limited financial innovations. The study further noted that real estate firms in Ghana did not have access to a variety of sources of venture capital this limiting their expansion. As a result, growth of the sector was also hampered due to inadequacy of venture capital. Whilst this study provides an 
International Journal of Current Aspects in Finance, Banking and Accounting, Volume 3, Issue 2, 2021 PP 79-103, ISSN 2707-8035

important discussion on venture capital, it did not consider the exact effect of private equity and other forms of venture on real estate growth rates. More so, the study was done in Ghana and not In Kenya and this is the reason that this study is being undertaken.

\subsubsection{Joint Venture and Growth of Real Estate Development}

Kimani and Memba (2017) did a study on factors that influence growth of real estate in Kenya. This study had the aim of ascertaining the existence of a relationship or otherwise between growth or real estate and Gross Domestic Product, exchange rates, inflation rates and interest rates. This study utilised secondary data that was mined from CBK and Hass Consultancy Publications. A correlation research design with time series analysis was used in getting inferences. The outcome of the study was that exchange rate, GDP and inflation positively influenced growth of real estate sector in Kenya. On the contrary, it was found out that interest rates was an impediment towards real estate growth rates. Whilst this empirical review present information on macroeconomic variables, it did not focus on firm specific financing options. It is for this reason that this study is being undertaken on order to narrow down to firm financing options.

Abdulatif and Almujamed (2017) did a study on joint venture and its associated success factors in Kuwait. The study examined the effect of partner selection, formulation of joint venture formations, regulatory considerations and implementation considerations on success of joint venture as strategic alliances. In order to get the inferences the researchers argued that the best framework was descriptive research design. First hand data was utilised through conducting interviews with real estate firms in the country. It was revealed that success of joint venture as strategic alliances depended on how well the three phases were done. Thus, the choice of partner, adherence to governance requirements and dealing with post implementation issues were critical success factors of joint venture. It is true to suffice that this study vitally provide information on joint venture process. However, it does not endeavour to document on effect of joint venture on real estate growth which forms the basic theme of this current study.

Hong and Chan (2014) studied the trend of joint venture and is effect on construction of in Hong Kong province in China. The objective was to establish the trend characteristics and construction status in China. This study was a content analysis of journal publications and articles. The study revealed that there were several methodologies that had previously undertaken in order to present information on joint venture which included: regression models, rank order analysis and structural equation models being the most common. Further, it was noted that joint ventures positively enhanced construction of real estates since they enabled the undertaking the huge investments, complex structures and enabled the integration of new skills into the businesses. Whilst the study provides content analysis of joint venture, the study fails to critically analyse effect of joint venture on real estate growth.

Minja, Kikwasi, and Thwala (2012) examined joint venture among construction firms in Tanzania. Their aim was to evaluate formation of joint venture, factors that influence the picking of joint venture and risks of joint ventures. The framework of data collection and analysis used as descriptive research design. First hand data was collected through issuance of questionnaires and interviews. It was revealed that legal requirements on joint venture registration, stability of partner, commitment and agreement risks were the main factors that affected joint venture agreements in Tanzania. Whilst this study provides information on joint ventures, the study did not consider impact of joint venture on growth of real estate. It is this reason that this current study is being undertaken with the aim of assessing effect of joint venture on growth real estate in Kenya. 
International Journal of Current Aspects in Finance, Banking and Accounting, Volume 3, Issue 2, 2021 PP 79-103, ISSN 2707-8035

\subsubsection{Financing Options, Firm Size and Real Estate Development}

Elston, Weidinger and Widmer (2018) carried out a study to determine the relationship between the size of a firm and its growth in United Arab Emirates (UAE). The choice of this location was because it was an emerging market. The major objective of the study was to examine the relationship between size and growth of listed firms in the United Arab Emirates. The target population was all the firms listed in the stock exchange of the United Arab Emirates. Secondary data was used for this study which was collected from the stock exchange commission as well as from the Audited financial statement of the selected firms. The study collected data was analysed by use of descriptive statistics, correlation analysis and regression analysis. The findings of this research was that there was a positive relationship between the firm size and its growth in the United Arab Emirates.

Purwohandoko ( 2017) carried out a research in Indonesia to find out the effect of firm size on its growth. The main objective of the study was to find out the effect of size, growth and profitability on corporate value with capital structure as the mediator. Secondary data was used for the study which was collected from the financial statements of the sampled firms. The study targeted agricultural companies and data was collected over a period of four years from 20112014. The target population was all the agricultural companies listed with the Indonesia stock exchange and a sample of fourteen companies was selected by use of purposive sampling. The data was analysed by use of partial least square method because the researcher used capital structure as a moderating factor. The findings of this study was that firm size and firm growth did not have any effect on capital structure and that the profitability of the firms affects the capital structure negatively.

Abbasi and Malik, (2015) did a study on the firm's size moderating financial performance in growing firms with an emphasis of firms in Pakistan. Their main objective was to point out the regulating stimulation of firm size between the connection between firm growth and profitability. The study used secondary cross-sectional data gathered from the firms listed in the Karachi stock exchange. The target population was fifty non-financial firms and data was reviewed for the year 2012. The data was analysed using descriptive statistics. The findings of this research is that firm size has a moderating effect on the firm growth and firm's performance.it is therefore right to say that firm's size affects its growth positively and therefore the management of firms should keep an eye on the size of the firm alongside its growth while working on ways to improve its performance.

Omar (2015) carried out a study to find out the relationship between firm size and financial performance of microfinance banks in Kenya. The main objective of the study was to examine the relationship between firm size and financial performance of microfinance banks in Kenya. The researcher used a descriptive research design. The target population was nine microfinance banks that had operation for a period of five years between 2010-2014.secondary data was used for the study which was obtained from the Central bank of Kenya and the Audited financial statements of the selected banks. The data collected was analysed by use of descriptive statistics, correlation analysis and regression analysis. The findings of this study was that due to their small size, microfinance banks had experienced tremendous growth in terms of customer deposits and this had led to improvement in performance.

\subsection{Conceptual Framework}

A research has its theme based on examination of variables where some variables are hypothesised to influence some other variables. A diagrammatic representation of hypothesis is known as conceptual framework (Kothari, 2004). It is important to note that a research has different variables depending on their nature. Mainly, there are two types of variables. 
International Journal of Current Aspects in Finance, Banking and Accounting, Volume 3, Issue 2, 2021 PP 79-103, ISSN 2707-8035

Variables that influence others are known as independent variables or predictors or explanatory variables (Cooper \& Schindler, 2014). Dependent variable is thought to be influenced by the independent variables and is also known as regressor. Mortgage, retained earnings, private equity and joint ventures were the predictors for this study while real estate's growth rates formed the regressor. The moderating variable of this study was size of real estate developers. This information is shown on Figure 1

\section{Independent Variables}

\section{Dependent Variable}

\section{Mortgage Financing}

4 Amount of mortgage

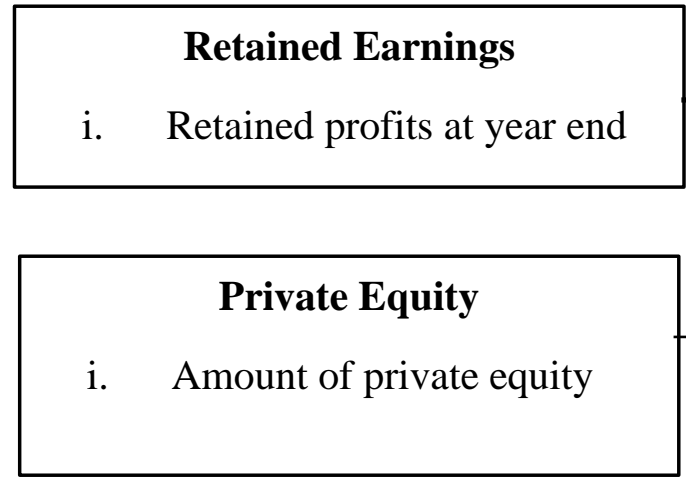

\section{Joint Venture}

1. Joint venture commitments
Growth Rates

Annualized Increase in number of housing units

\section{Moderating variable}

2. Firm Size of the real estate developer measured by natural $\log$ of total assets

Source (Author, 2019)

Figure 1 Conceptual Framework

\subsection{Research Methodology}

\subsection{Research Design}

This study adopted the descriptive research design. A descriptive research design has one basic theme which is centred on describing the existence or not of relationship between or among a given set of variables. The variables that are assumed to affect the other variables are called predictor variables or independent variables (Kothari, 2004). In the light of this purpose, the best design for this study is therefore, the descriptive research design.

\subsection{Target Population}

The target population of this study was all firms that are members of Kenya Property Developers Association. There are 72 firms that are registered in different member categories as at March 2019 (KPDA, 2019). 
International Journal of Current Aspects in Finance, Banking and Accounting, Volume 3, Issue 2, 2021 PP 79-103, ISSN 2707-8035

\subsection{Sample and Sampling design}

Using a convenience sampling technique, a sample of 23 firms was selected from the 72 (KPDA) members was used. In choosing a sample, the practicalities and cost of undertaking a census, representativeness and the nature of the survey as well as population was considered.

\subsection{Data Collection Procedure}

The study seeks to use secondary data that was obtained from the annual audited financial statements and periodicals of the firms and data was collected for the period between 2014 and 2018. Thus, data was collected for a period of five years. This period is adequate for a panel data analysis.

\subsection{Data Analysis Technique}

Data analysis is a step by step process of seeking to find inferences from raw data. Data analysis is a process that should be done in line with the research design and the objectives of a given study (Kothari, 2004). The best method of data analysis for this study is panel data analysis. This method is preferred since it enables the selection of the right model for reporting findings together with ensuring that diagnostics are critically done before conclusions are made. This study used STATA Version 12 in carrying out data analysis.

\subsection{Analytical Model}

An analytical model is function that is hypothesised in order to connect the predictors with the dependent variable. The function has been set as:

$\mathbf{G R}_{\text {it }}=\beta_{0}+\beta_{1}$ MFit $+\beta_{2} R_{\text {it }}+\beta_{3} P_{\text {it }}+\beta_{4} J_{V_{i t}}+\varepsilon i t$

Where GR is the proxy to annualised growth rate in number of housing units,

$\mathrm{MF}$ is mortgage financing of each real estate developer,

$\mathrm{RE}$ is retained earnings of each real estate developer,

$\mathrm{PE}$ is private equity of each real estate developer,

$\mathrm{JV}$ is joint ventures of each real estate developer,

$i$ is individual real estate developer.

$\mathrm{t}$ is time, that is, from 2014 to 2018.

$\mathrm{B}_{\mathrm{o}}$ is the constant in the estimation model

$\mathrm{B}_{1}, \mathrm{~B}_{2}, \mathrm{~B}_{3}, \mathrm{~B}_{4}$ are the coefficients that define nature of effect of each regressors

$\varepsilon$ it is the error term.

\subsubsection{Moderating Effect}

The study has firm size as a moderating variable. A moderating variable is a predictor that tentatively affects the nature and magnitude of the association between regressor and the explanatory variables. Total assets was used as the proxy to firm size. On including firm size, the analytical model was:

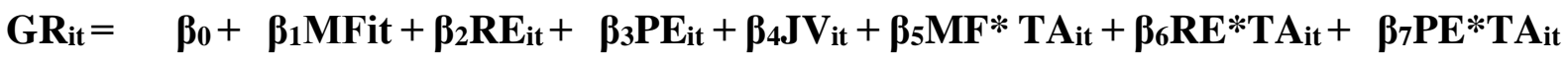
$+\beta_{8} J V^{*} \mathbf{T A} A_{i t}+\varepsilon_{i t}-----($ ii)

Where TA is total assets and the other abbreviations are as expressed in equation (i) 
International Journal of Current Aspects in Finance, Banking and Accounting, Volume 3, Issue 2, 2021 PP 79-103, ISSN 2707-8035

The study adopted zero order model in testing for moderating effect of firm size on growth of real estate in Kenya. In so doing, the interaction between the independent variables was tested for moderation where the P-value of new iterated variables was examined.

\subsection{Data Analysis Results}

\subsection{Correlation Analysis}

Correlation analysis evaluates the strength of variables. This is important as it shows whether variables are related or not. Correlation analysis was done by use of the ratio as operationalised in this study. The result for correlation analysis are shown on

Table 1.

Table 1 Matrix of Correlations

\begin{tabular}{lrrrrrr}
\hline Variables & $(1)$ & $(2)$ & $(3)$ & $(4)$ & $(5)$ & $(6)$ \\
\hline (1) m_ratio & 1.000 & & & & & \\
(2) re_ratio & -0.004 & 1.000 & & & & \\
(3) pe_ratio & -0.116 & -0.035 & 1.000 & & & \\
(4) jv_ratio & -0.093 & -0.028 & -0.042 & 1.000 & & \\
(5) logFS & 0.030 & 0.031 & 0.054 & -0.043 & 1.000 & \\
(6) growth_rate & -0.030 & -0.108 & 0.159 & -0.096 & -0.119 & 1.000 \\
\hline
\end{tabular}

In relation to the statistics on Table 1 , mortgage financing had a negative correlation with retained earnings, private equity, joint venture and growth rate at $-0.004,-0.116,-0.093$ and 0.030 respectively. However, mortgage financing had positive correlation with firm size as 0.030. Retained earnings had a negative correlation with private equity, joint venture, and growth rate at -0.108 and positive correlation with firm size at 0.031 . Private equity correlated negatively with joint venture at -0.042 and positively with both firm size and growth rates at 0.054 and 0.159 . Joint venture had a negative correlation with both firm size and growth at 0.043 and -0.096 respectively. Lastly, firm size had a negative correlation with growth rate at -0.119. This result indicate that variables had different associations with other variables. Moreover, the individual explanatory variables association with output variable is significantly high. However, this does not statistically infer cause and effect which is presented in the ensuring section.

\subsection{Regression Coefficients}

The estimation of regression coefficients was done using robust standard errors model since the data set suffered from serial correlation problem. Moreover, model specification was not done since one assumption of no serial correlation failed. The study had four explanatory variables (mortgage financing, retained earnings, private equity and joint venture).The panel corrected standard errors regression result is shown on Table 2. 
International Journal of Current Aspects in Finance, Banking and Accounting, Volume 3, Issue 2, 2021 PP 79-103, ISSN 2707-8035

Table 2 Prais-Winsten regression, heteroskedastic panels corrected standard errors (Model 1 )

\begin{tabular}{|c|c|c|c|c|c|}
\hline growth_rate & Coef. & St.Err & t-value & p-value & Sig. \\
\hline m_ratio & -0.005 & 0.045 & -0.11 & 0.917 & \\
\hline re_ratio & -0.001 & 0.000 & -3.80 & 0.000 & $* * *$ \\
\hline pe_ratio & 0.000 & 0.000 & 5.62 & 0.000 & $* * *$ \\
\hline jv_ratio & 0.000 & 0.000 & -1.05 & 0.292 & \\
\hline _cons & 0.543 & 0.010 & 55.27 & 0.000 & $* * *$ \\
\hline Mean dependent var & 0.548 & \multicolumn{2}{|c|}{ SD dependent var } & & 0.115 \\
\hline R-squared & 0.860 & \multicolumn{2}{|c|}{ Number of obs } & & 115.000 \\
\hline Chi-square & 50.307 & \multicolumn{2}{|c|}{ Prob > chi2 } & & 0.000 \\
\hline
\end{tabular}

On Table 2, the model is statistically significant as shown by the probability is greater than chi- square statistic of 0.000 that is less than 0.05 . The coefficient of determination as shown by $\mathrm{R}^{2}$ is 0.860 which means that 86.0 percent of variations in real estate growth rate is accounted for by changes in mortgage financing, retained earnings, private equity and joint venture financing.

Moreover, the effect of mortgage financing retained earnings is negative while private equity and joint venture positively impacts on real estate growth rate. Of the four predictors, only retained earnings and private equity significantly influences growth of real estates as shown by the $\mathrm{p}$-value of 0.0000 that is less than 0.05 . The fourth objective of this study was to examine the moderating effect of firm size on financing options and the resultant effect on real estate growth rate in Kenya. The result of the estimation is shown on Table 3.

Table 3 Prais-Winsten regression, heteroskedastic panels corrected standard errors (Model 2)

\begin{tabular}{lclrrr}
\hline growth_rate & Coef. & St.Err & t-value & p-value & Sig. \\
\hline m_ratio & 0.330 & 0.238 & 1.39 & 0.166 & \\
re_ratio & 0.003 & 0.007 & 0.38 & 0.705 & \\
pe_ratio & 0.000 & 0.002 & -0.01 & 0.993 & \\
jv_ratio & 0.000 & 0.001 & -0.11 & 0.916 & \\
X5 & -0.016 & 0.011 & -1.50 & 0.134 & \\
X6 & 0.000 & 0.000 & -0.47 & 0.637 & \\
X7 & 0.000 & 0.000 & 0.09 & 0.928 & \\
X8 & 0.000 & 0.000 & 0.06 & 0.950 & $* * *$ \\
_cons & 0.542 & 0.010 & 55.41 & 0.000 & \\
& & & & & 0.115 \\
Mean dependent var & & 0.548 & SD dependent var & & 0.000 \\
R-squared & 0.854 & Number of obs & & \\
Chi-square & 60.209 & Prob $>$ chi2 & & \\
& & & & & \\
*** $\mathrm{p}<0.01, * * \mathrm{p}<0.05, * \mathrm{p}<0.1$ &
\end{tabular}

Pegging on results on Table 3, the model efficiency reduces on moderation as the $\mathrm{R}^{2}$ has reduced to 0.854 from 0.860 noted in absence of moderator variable. However, the model is statistically significant as shown by p-value of 0.000 . Moreover, only two variables private equity and moderate private equity) are statistically significant. Hence, firm size was noted not 
International Journal of Current Aspects in Finance, Banking and Accounting, Volume 3, Issue 2, 2021 PP 79-103, ISSN 2707-8035

be a moderator on the model that sought to estimate the effect of financing options on real estate growth rates in Kenya. Having noted this, firm size was treated as an explanatory variables and the results are illustrated on Table 4.9

Table 4 Prais-Winsten regression, heteroskedastic panels corrected standard errors (Model 3)

\begin{tabular}{lrlrrr}
\hline growth_rate & Coef. & St.Err & t-value & p-value & Sig. \\
\hline m_ratio & 0.015 & 0.047 & 0.32 & 0.750 & \\
re_ratio & -0.001 & 0.000 & -2.65 & 0.008 & $* * *$ \\
pe_ratio & 0.000 & 0.000 & 6.67 & 0.000 & $* * *$ \\
jv_ratio & 0.000 & 0.000 & -1.06 & 0.291 & \\
logFS & -0.009 & 0.004 & -2.13 & 0.033 & $* *$ \\
_cons & 0.720 & 0.085 & 8.48 & 0.000 & $* * *$ \\
& & & & & \\
\hline Mean dependent var & & 0.548 & SD dependent var & & 0.115 \\
R-squared & 0.876 & Number of obs & & 0.000 \\
Chi-square & 56.844 & Prob > chi2 & &
\end{tabular}

$* * * \mathrm{p}<0.01, * * \mathrm{p}<0.05, * \mathrm{p}<0.1$

Considering the statistics on Table 4 , the $\mathrm{R}^{2}$ was 0.876 which implies that 87.6 percent of variations in real estate growth in Kenya is influenced by changes in financing options, that is, mortgage financing, retained earnings, private equity, joint venture and firm size. The other 12.4 percent variation in real estate growth rate is influenced by other factors other than those considered in this study. In terms of model efficacy, the overall model is statistically significant as the $\mathrm{p}$-value is 0.0000

The estimated model was established and rewritten:

$\mathrm{GR}_{\mathrm{it}}=0.720+0.015 \mathrm{MFit}-0.001 \mathrm{RE}_{\mathrm{it}}+0.0001 \mathrm{PE}_{\mathrm{it}}+0.0001 \mathrm{JV}_{\mathrm{it}}-0.009 \mathrm{FS}_{\mathrm{it}}$

Whereas:

0.720 is the real estate growth rate in absence of predictor variables, +0.0015 is the increase in real estate growth rate in response to a one unit increase in use of mortgage financing, -0.001 is the decrease in real estate growth rate in response to one unit increase in use of retained earnings as source of financing, 0.0001 is the increase in real estate growth rate in response to an increase in use of private equity as financing option, 0.0001 is the increase in real estate growth rate in response to an increase in joint venture arrangement and -0.0009 is the decrease in real estate growth rate in response to increase in firm size.

The general objective of this study is to assess the role of financing options on growth rate of real estate development in Kenya. Four predictors were selected and results obtained by use of Prais Winstein regression analysis for panel corrected standard errors. The results showed that financing options influenced growth rate of real estate development companies in Kenya. This is because the overall model fitness was upheld as the p-value was 0.0000 which was less than alpha value of 0.05 . This is a pointer that it is statistically sound to relate financing options with growth rates of real estate development companies in Kenya. Moreover, the coefficient of determination depicted by an $\mathrm{R}^{2}$ of 0.876 was high which then means that a high variation (87.6 percent ) of growth rates of real estate development companies is influenced by corresponding changes in mortgage financing, retained earnings, private equity, joint venture and firm size.

On whether, mortgage financing influences growth rate of real estate development companies in Kenya, the study found out that mortgage financing positively but insignificantly influences 
International Journal of Current Aspects in Finance, Banking and Accounting, Volume 3, Issue 2, 2021 PP 79-103, ISSN 2707-8035

growth rate of real estate development companies in Kenya. This is because the coefficient was positive and the p-value was 0.750 which led to failure in rejection of null hypothesis. This is to mean that mortgage financing has potential though not significantly to enhance growth rates of real estate entities in Kenya. Mortgage depicts a financial arrangement between the buyer of a real estate unit and the real estate developer where the buyer does not pay the full amount for the unit but pays periodic instalments for a specified period of time. In this aspect therefore, mortgages may not provide immediate funds for use in expansion of firm activities as receipts are spread over time. However, it is plausible investment platform which house buyers considers as the instalments are less over a long period of time. This result is agreement with those of Glaeser, Huang, Ma and Shleifer (2017) who reported that mortgage improved growth rates of real estate development companies in China. Adetiloye and Eke (2016) aslso noted that mortgage financing improves growth rates of real estate firms in Nigeria. Still, Kioko (2014) revealed that mortgage had a positive influence on real estate performance. This was attributed to the idea that mortgage financing facilitates home owners to acquire housing units without the total cash price of the houses.

The study revealed that retained earnings did not improve growth rates of real estate development in Kenya. This is because, the coefficient was negative. Moreover, the relationship between retained earnings and growth rate of real estate firms was statistically significant. Use of retained earnings limits expansion activities especially where the ploughed back profits is low. This finding contradicts that of Ogbenjuwa, Egbu, and Robinson (2018) examined the real estate finaincing challanges in Nigeria and indicated that internal sources of funds enhances real estate developemnt. However, this finding agrees with that of Mustaruddin, Zahirdin, and Octaviani (2017) who assesed ownership structure and its potential effect on corporate performance of real estate firms in Indonesi and noted that internal sources limited expansion activities.

The study found out that private equity positively and significantly influences growth rates of real estate development companies in Kenya. This means that private equity financing is a key determinant of growth of real estate in Kenya. However, a research done in Nigeria by Dabara, Omotohinshe, Chiwuzie, and Olusula (2018) on examined Real Estates Investments Trusts(REITS) among real estate develoeprs in Nigeria revealed that private equity did not improve growth of real estate firms. In Ghana, Kissi, Duodu, and Somiah (2016) noted that access to venture capital through private equity financing improves growth of real estate sector.

This study found out that joint venture improves growth rates of real estate development companies in Kenya in a nonsignificant manner. In this respect, joint venture is not a deteriminant of growth. This result matches that of Abdulatif and Almujamed (2017) who did a study on joint venture and its associated success factors in Kuwait and reported that joint venture positively growth of real estate but the level of influence depends on nature of joint ventures. Similarly, Hong and Chan (2014) studied the trend of joint venture and its effect on construction of in Hong Kong province in China and revealed that joint venture improves growth rates of construction sector in the region.

The moderating effect of firm size was minimal and therefore the variable was treated as an explanatory one. Pertaining to role of firm size on growth rates of real estate development companies in Kenya, the study revealed that firm size hampers growth rates in a statistically significant manner. This result contradicts with those of Abbasi and Malik, (2015) who did a study on the firm's size moderating financial performance in growing firms with an emphasis of firms in Pakistan and reported that firm size was a moderating variable on growth of firms. Firm size represents the ability to invest and take up opportunities in the market plays an instrumental role in ensuring that firms grow and exhibit sustained performance. Since firm 
International Journal of Current Aspects in Finance, Banking and Accounting, Volume 3, Issue 2, 2021 PP 79-103, ISSN 2707-8035

size is conventionally proxied by total assets, it follows that firm size impacts growth of firms in a positive way only if such resources are prudently expended.

\subsection{Conclusions and Recommendations 5.1 Conclusions}

The study concluded that mortgage financing positively impacts on growth rates of real estate development companies in Kenya. In addition, the relationship between mortgage financing and growth rates of real estate development companies was found to be insignificant. This can be attributed to the fact that mortgages spreads the receipts as the repayment is for a long term. Hence, mortgages hold funds that could be used in construction of new housing units if were paid upfront. Nevertheless, mortgage financing makes housing units affordable and this has a potential of increasing the demand for houses thus the positive but insignificant effect of mortgage financing on growth rates of real estate development companies in Kenya.

The study concluded that retained earnings negatively affects growth rates of real estate development companies in Kenya. Moreover, the effect of retained earnings was noted to be statistically significant. This is to indicate that use of profits to finance activities of real estate companies does not improve their growth. Arguably, where retained earnings is low then the funds for investments are low and this limits expansion activities. Entities with higher profits are in a better position to apportion some to projects thus increasing growth rates. The reverse case is true in that loss making firms find it difficult to expand activities.

The study concluded that private equity positively impacts on growth rates of real estate development in Kenya. Moreover, the relationship between private equity and growth rates of real estate was found to be statistically significant. Private equity is financial market development in which partners join efforts to undertake capital intensive projects. It has become a common practice among real estate development companies in Kenya since private equity enables acquisition of start-up capital and any necessary finances after construction has ended. The study concluded that joint venture positively impacts on growth rates of real estate development companies in Kenya. In addition, this study concludes that joint venture insignificantly influences growth rates of real estate development companies in Kenya. Joint venture enables access to technologies, entry to new markets, sharing of risks and exchange of managerial skills and expertise. However, joint venture requires partnering firms to be on the same level in terms of financial power and therefore such arrangements are uncommon. It is for this reason that joint venture perhaps influences growth rates of real estate development companies insignificantly. Nevertheless, joint venture creates synergies for companies. The study concluded that firm size did not have any moderating effect on growth rates of real estate development companies in Kenya. Firm size acted more informative as an explanatory variables. Moreover, this concluded that firm size does not boost growth of real estate development companies in Kenya. Firm size was proxied by natural log of total assets and this may have led to this conclusion. A firm can have a huge balances of total assets and this could be due to funds not in usable forms such as inventory or finished units which in the current time may not provide funds for more investments.

\subsection{Recommendations}

Real estate development companies in Kenya should seek private equity as a source of financing options since this was found to have the most significant positive effect. Private equity is profound as it leads to sharing of risks and acquisition of skills and this leads to a boost in growth rate of real estate development companies in Kenya. The government of Kenya should equally establish laws governing private equity arrangement as it is a new concept in 
International Journal of Current Aspects in Finance, Banking and Accounting, Volume 3, Issue 2, 2021 PP 79-103, ISSN 2707-8035

Kenya. This would go a long way towards streamlining the arrangements and ultimately lead to real estate development companies' growth.

Secondly, firms should prudently enter into joint venture and mortgage financing as both have positive yet insignificant effect on growth rates of real estate development companies. In particular, mortgages should be made affordable to house buyers as this can increase the demand for more houses. Real estate development companies should also form strategic alliances in form of joint venture in order to undertake more projects and complete more housing units. As a policy recommendation, the government of Kenya should enter into joint ventures with real estate development companies in its Affordable Housing Projects. This enhances growth rates of real estate development companies in turn.

\section{References}

AAK. (2011). July Monthly Report. Nairobi: Architectural Association of Kenya.

Abbasi, A., \& Malik, Q. A. (2015). Firms' size moderating financial performance in growing firms: an empirical evidence from Pakistan. International Journal of Economics and Financial Issues, , 5(2), 334-339.

Abdulatif, A. A., \& Almujamed, H. I. (2017). Joint ventures in the real estate sector: the critical factors to consider for success . Journal of Global Business Advancement, 10(1),89107.

Abdulrehman, A. A., \& Nyamute, W. (2018). Effect of mortgage financing on financial performance of commercial banks in Kenya. Journal of International Business, Innovation and Strategic Management, 1(6), 91- 12.

Adetiloye, A. K., \& Eke, P. O. (2016). Financial architecture, real estate market and economic development in sub-saharan African countries: evidence from Nigeria. Journal of South African Business Research, 2-16.

Adetiyole, K. (2013). The national housing fund, mortgage finance and capital formation in Nigeria. International Journal of Business and Social Research, 3(7):43-53.

Adnan, H., Chong, H. Y., \& Morledge, R. (2011). Success criteria for international joint ventures: the experience of Malaysian contractors in the Middle East. African Journal of Business Management, 5(13), 5254-5260.

Anyanzwa, J. (2018, September 25). Why East Africa's real estate investment scheme failed to excite investors. Retrieved from The East African: https://www.theeastafrican.co.ke/business/East-Africa-real-estate-investment-failedto-excite-investors/2560-4776616-13jdlll/index.html

Aondohemba, S, A., \& Lawrence, O. U. (2015). Investment performance indicators of selected Lagos commercial properties. Journal of Property Investment \& Finance, 34(1):83-97.

Bahli, B., \& Rivard, S. (2017). The information technology outsourcing risk: a transaction cost and agency theory-based perspective. In Outsourcing and Offshoring Business Services (pp. 53-77). Montreal: Springer International Publishing.

Baker, J. K., \& Wiedemer, J. P. (2012). Real Estate Finance, 9th edition. Mason: Cengage Learning.

Bell, A., \& Jones, K. (2015). Explaining fixed effects: random effects modeling of time-series cross-sectional and panel data. Political Science Research and Methods, 3(1), 133-153.

Bell, A., \& Jones, K. (2015). Explaining Fixed Effects: Random Effects Modeling of TimeSeries Cross-Sectional and Panel Data. Political Science Research and Methods, 3(1), 133-153.

Bianco, M., \& Yoshino, J. (2012). Firm market performance and volatility in a national real estate sector. International Review of Economics \& Finance, 22(1): 230-253.

Brooks, C. (2008). Introductory econometrics for finance, 2nd Edition. Cambridge, United Kingdom: Cambridge University. 
International Journal of Current Aspects in Finance, Banking and Accounting, Volume 3, Issue 2, 2021 PP 79-103, ISSN 2707-8035

Brooks, C. (2008). Introductory Econometrics for Finance, 2nd Edition. Cambridge, United Kingdom: Cambridge University.

CAHF. (2012). Housing Finance in Africa. A review of some of Africa's housing finance markets (2016 Year. Midrand: Centre for Affordable Housing Finance in Africa.

Cambria, E., Poria, S., Bajpai, R., \& Schuller, B. (2016). SenticNet 4: a semantic resource for sentiment analysis based on conceptual primitives. The 26th International Conference on Computational Linguistics (pp. 2666-2677). Osaka, Japan: Coling.

CBK. (2014). The Kenya Financial Sector Stability Report. Nairobi: Central Bank of Kenya.

CBK. (2018). Banking sector annual report. Nairobi: Central Bank of Kenya.

Cechetti, S. G., \& Kharroubi, E. (2015, June 29). Why does financial sector growth crowd out real economic growth? CEPR Discussion Paper No. DP10642, p. 33.

Chan, D., \& Kumaraswamy, M. (2010). A comparative study of causes of time overruns in Hong Kong construction projects. International Journal of Project Management, 15(1),55-63.

Clark, T. S., \& Linzer, D. (2019, March 16). Should I use fixed or random effects? Retrieved from https://datajobs.com/data-science-repo/Fixed-Effects-Models-[Clark-andLinzer].pdf accessed 1/6/2017

Clark, T. S., \& Linzer, D. (2019, March 16). Should I Used Fixed or Random Effects? Retrieved from https://datajobs.com/data-science-repo/Fixed-Effects-Models-[Clark-andLinzer].pdf accessed 1/6/2017

Clauretie, T. M., \& Sirmans, G. S. (2012). Real Estate Finance: Theory \& Practice (6th ed). Mason: Cengage Learning.

Cooper, D., \& Schindler, P. (2014). Business Research Methods. Boston: Macgraw-Hill/Irwin.

Creswell, J., Vicki, L., \& Clark, P. (2011). Designing and conducting mixed methods research. Los Angeles: Sage Publications.

Cytonn. (2018). 2018 Residential Report. Nairobi: Cytonn Research.

Cytonn. (2019, February 11). Cytonn. Retrieved from https://cytonn.com/topicals/affordablehousing-in-kenya

Dabara, D. I., Omotohinshe, J. O., Chiwuzie, A., \& Olusula, A. (2018). The market structure of real estate investments trusts in Nigeria. International Journal of Arts \& Sciences, 11(3),101-112.

Dan, L. X., Nan, F. X., \& Yuan, S. X. (2015). The determinants of capital structure choice for Chinese listed companies based on structural equation modeling approach. International Journal of Mathematics, Game Theory and Algebra, 24(2-3):77-103.

Elston, J. A., Weidinger, A., \& Widmer, M. (2018). An examination of the relationship between size and growth of listed firms in the United Arab Emirates. The Business and Management Review, 9(4), 13-21.

Esarey, J., \& Jaffe, J. (2017, March 19). A direct test for consistency of random effects models that outperforms the hausman test. 2017 Time and Space conference at Texas A\&M University. Texas: Texas A\&M University. Retrieved from A Direct Test for Consistency of Random Effects Models that Outperforms the Hausman Test*: https://polmeth.polisci.wisc.edu/Papers/2017-7-12_hausman-alternative-paper_1.pdf

Europen Commission. (2019, October 2). Real estate activity statistics - NACE Rev. 2. Retrieved from European Commission: https://ec.europa.eu/eurostat/statisticsexplained/index.php/Real_estate_activity_statistics__NACE_Rev._2\#Sectoral_analysis

Frappa, S., \& Mesonnier, J. S. (2010). The hausing price boom of the late 1990s: did inflation targeting matter. Journal of Financal Stability, 6(4): 243-254.

Glaeser, E., Huang, W., Ma, Y., \& Shleifer, A. (2017). A real estate boom with Chinese characteristics. Journal of Economic Perspectives, 31(1):93-116. 
International Journal of Current Aspects in Finance, Banking and Accounting, Volume 3, Issue 2, 2021 PP 79-103, ISSN 2707-8035

Golob, K., Bastic, M., \& Igor, P. (2012). Analysis of impact factors on the real estate market: case Slovenia. Inzinerine Ekonomika-Engineering Economics, 23(4): 357-367.

Grant, C., \& Osanloo, A. (2016). Understanding, selecting and integrating a theoretical framework in dissertation research: creating the blueprint for your house. Administrative Issues journal, 4(2), 12-26.

Groh, A. P., \& Leiser, K. (2014). The determinants of international commercial real estate investment. Journal of Real Estate Finance and Economics, 48:611-659.

Guran, C., Volovelsky, E. K., \& Dana, L.-P. (2018). The path of a successful entrepreneurial sojourner: a case study about Ilan Maimon. Diaspora Networks in International Business, 373-390.

Hajli, N. M., Shanmugam, M., Khani, H. A., Hajli, A., \& Wang, Y. (2015). Health care development: integrating transaction cost theory with social support theory. Journal for Informatics for Health and Social Care, 40(5),334-344.

Harasim, L. (2017). Learning Theory and Online Technologies. New York: Routledge.

Harris, T. (2017). You can't lock the doors! are lenders powerless to stop zombie properties in lien theory states? Real Property, Probate and Trust Law Journal, 17(2), 17-23.

Hausman, J. A. (1978). Specification tests in econometrics. Econometrica, 46: 1251-1271.

HHK. (2019, February 11). Habitat for Humanity in Kenya. Retrieved from Habitat for Humanity in

Kenya: https://www.habitat.org/sites/default/files/documents/EMEA_Kenya.pdf

Hoesli, M., \& Reka, K. (2013). Volatility spillovers, comovements and contagion in securitized real estate markets. Journal of Real Estate Finance and Economics, 47:1-35.

Hong, Y., \& Chan, D. W. (2014). Research trend of joint ventures in construction: a two-decade taxonomic review. Journal of Facilities Management, 12(2),118-141.

Huang, X. W., \& Ma, Y. H. (2015). Research on the influence of real estate investmentand economic growth in China. International Conference on Management Engineering and Management Innovation (ICMEMI).

Hubbard, G. (2013). Successful utility project management from lessons learned. Project Management Journal, 21(3), 19-23.

Ibem, E. O. (2010). An assessment of the role of government agencies in public-private partnerships in housing delivery in Nigeria. Journal of construction in developing countries, 5(2):23-48.

ISOCARP. (2010). The 46th ISOCARP Congress on "Sustainable City / Developing World". Nairobi: ISOCARP.

Jaffe, J., \& Esarey, J. (2017, March 19). A direct test for consistency of random effects models that outperforms the Hausman Test. 2017 Time and Space conference at Texas A\&M University. Texas: Texas A\&M University. Retrieved from A Direct Test for Consistency of Random Effects Models that Outperforms the Hausman Test*: https://polmeth.polisci.wisc.edu/Papers/2017-7-12_hausman-alternative-paper_1.pdf

Janot, A., Vandonjon, P. O., \& Gaitier, M. (2016). A revised Durbin-Wu-Hausman test for industrial robot identification. Control Engineering Practice, 48,52-62.

Juma, I. M. (2014). The effect of macroeconomic variables on growth in real estate investment in Kenya. Unpublished Msc project. Nairobi. Nairobi: University of Nairobi.

Jumbale, D. K. (2012). The relationship between house prices and real estate financing in Kenya. Unpublished MBA project. Nairobi, Kenya: University of Nairobi.

Ketokivi, M., \& Mahoney, J. T. (2018). Transaction cost economics as a constructive stakeholder theory. Academy of Management Learning \& Education, 15(1),74-89.

Kibunyi, D., Ndiritu, S. W., Carcel, H., \& Alana, G. L. (2017). Real estate prices in Kenya: is there a bubble? Journal of Housing and the Built Environment, 1(2),24-31. 
International Journal of Current Aspects in Finance, Banking and Accounting, Volume 3, Issue 2, 2021 PP 79-103, ISSN 2707-8035

Kimani, J. N., \& Memba, F. (2017). Factors affecting the growth of real estate in Kenya. International Journal of Management and Commerce Innovations, 4(2),531-549.

Kioko, F. N. (2014). Effect of mortgage financing on performance of real estate market in Kenya. Unpublished MBA Project.

Kioko, F. N. (2014). Effect of Mortgage Financing on Performance of Real Estate Market in Kenya. Unpublished MBA Project.

Kissi, E., Duodu, A. A., \& Somiah, M. K. (2016). Factors influencing venture capital financing of real estate development in Ghana. African J. Economic and Sustainable Development, 5(4),355-364.

Kitavi, S. M. (2013). Effect of mortgage finance on development of real estate in Nairobi county. Unpublished MBA Project, University of Nairobi.

KNBS. (2014). Kenya National Housing Survey; Basic report 2012-2013. Nairobi: Kenya Nationa Bureau of Statistics/ Government of Kenya.

KNBS. (2018). Real Estate and Construction Statistics. Nairobi: Kenya National Bureau of Statistics.

Knight Frank. (2019, 10 24). Kenya insights 2018; assessing key trends across Kenya's prime residential markets. Retrieved from Knightfrank website: https://content.knightfrank.com/research/1437/documents/en/kenya-insight-20185215.pdf

Kothari, C. R. (2004). Research Methodology. New Delhi: New Age Publications.

KPDA. (2019, March 19). Kenya Property Developers Association. Retrieved from http://www.kpda.or.ke/documents/KPDA\%20Directory\%20of\%20Members\%20in\%2 0Good\%20Standing,\%206th\%20March\%202019.pdf

Leedy, P. D., \& Ormond, J. E. (2010). Practical Research: Planning and Design, 9th Edition. New York City: Merril.

Leedy, P. D., \& Ormond, J. E. (2010). Practical Research: Planning and Design, 9th Edition. New York City: Merril.

Leiser, K., \& Groh, A. P. (2010). The Determinants of International Commercial Real Estate Investments. The Journal of Real Estate, 4(2):10-15.

Leung, L. (2015). Validity, reliability, and generalizability in qualitative research. Journal of Family Medicine and Primary Care, 4(3),324-327.

Lloyd, W. H. (1923). Mortgages. The Genesis of the Lien Theory. The Yale Law Journal Company, Inc, 32(3),233-246.

Lynne, D. R. (2015). Ethical Issues in Conducting Qualitative Research in Online Communities. Qualitative Research in Psychology, 12(3),314-325.

Macharia, C. (2019, February 12). Knight Frank. Retrieved from Kenya Insights: https://content.knightfrank.com/research/1437/documents/en/kenya-insight-20185215.pdf

Macharia, E. W. (2013). The effects of global financial crisis on the financial performance of commercial banks offering mortgage finance in Kenya. International Journal of social sciences and entrepreneurship, 1(2):688-701.

Majluf, N. S., \& Myers, S. C. (1984). Corporate Financing and Investment Decision: When Firms have Information that Investors do not have? Journal of Financial Economics, $13 ; 187-221$.

Manu, O., Edwards, D. J., Badu, E., Hyiaman, D. K., \& Love, P. E. (2015). Real estate infrastructure financing in Ghana: Sources and constraints. Habitat International, $50,35-41$.

Marcum, B., \& Goddard, J. (2012). Real Estate Investment: A Value Based Approach. Winston-Salem: Springer Publications. 
International Journal of Current Aspects in Finance, Banking and Accounting, Volume 3, Issue 2, 2021 PP 79-103, ISSN 2707-8035

Mathews, J., \& Robinson, W. (2018). Social media and radiography research: Ethical considerations. Radiography, 24(2),96-97.

Mati, L. M., \& Makori, M. (2014). Effects of Economic Factors on Performance of Real Estate in Kenya. European Journal of Business Management, 1 (11), 181-200.

Mauck, N., \& Price, M. S. (2017). Determinants of Foreign Versus Domestic Real Estate Investment: Property Level Evidence from Listed Real Estate Investment Firms. The Journal of Real Estate Finance and Economics, 54(1):17-57.

Meseko, A. A. (2014). Opportunities \& Risks for Foreign Real Estate Developers in Nigeria. Journal of Economics, Commerce and Management, 2(7):1-6.

Messah, O. B. (2011). Factors influencing real estate property prices; A survey of real estates in. Journal of economics and sustainable development, 2(4).

Minja, S. J., Kikwasi, G. J., \& Thwala, W. D. (2012). A study of Joint Venture Formation Between Construction Organisations in Tanzania. Australasian Journal of Construction Economics and Building Conference Series, 1(2),32-42.

Mohamed, S., \& Baum, A. (2016). Determinants of Foreign Direct Real Estate Investment in selected MENA countrie. Journal of Property Investment \& Finance, 3(2):116-142.

Mugenda, O. M., \& Mugenda, A. G. (2012). Research Methods quantitative and Qualitative Approaches. Nairobi: Applied Research and Training Services Press.

Mugenda, O. M., \& Mugenda, A. G. (2012). Research Methods: Quantitative and Qualitative Approaches. Nairobi: African Centre for Technology Studies.

Mungai, D. (2016). Role of Financing Options on the Growth of Real Estate in Kenya, a survey of Real Estate Developers in Nairobi Metropolis. Unpublished MBA project, KCA University.

Mustaruddin, S., Zahirdin, G., \& Octaviani, E. (2017). Ownership Structure and Corporate Performance: Evidence from Property and Real Estate Public Companies in Indonesia. Investment Management and Financial Innovations Journal, 14(2-1), 252-263.

Mwangi, I. K. (2012). The nature of Rental Housing in Kenya, Environment and Urbanization. Journal of Real Estate Literature, 9,91-116.

Mwathi , J., \& Karanja, J. M. (2017). The Effect of Financing Sources on Real Estate Development in Kenya. International Journal of Finance and Accounting, 2(5),43-62.

Needleman, L. (1965). The Economics ofmHousing. London: Staples Press.

Nguyen, N. T., Nguyen, L. P., \& Dang, H. T. (2017). Analyze the Determinants of Capital Structure for Vietnamese Real Estate Listed Companies. International Journal of Economics and Financial Issues, 7(4):270-282.

Nicolás , C., \& Alexander, W. (2017). The view from Vienna: An analysis of the renewed interest in the Mises-Hayek theory of the business cycle. The Review of Austrian Economics, 30(2), 169-192.

Nicolas, C., \& Peter, L. (2016). Financial Foundations of Austrian Business Cycle Theory, in (ed. Studies in Austrian Macroeconomics (Advances in Austrian Economics, 20(1),1544.

Nikolaos, K., Dimitra, V., \& Agapi, X. (2011). Real Estate Values and Environment: A case Study on the Effects of the Environment on Residential Real Estate Values. International Journal of Academic Research, 3(1): 861-868.

Noppen, V. A. (2012). The ABC's of Affordable Housing in Kenya. Nairobi: The Acumen Fund.

Nzalu, F. M. (2012). An assessment of the factors affecting the growth in Real Estate Investment in Kenya. Unpublished MBA Project, Nairobi. Nairobi: University of Nairobi. 
International Journal of Current Aspects in Finance, Banking and Accounting, Volume 3, Issue 2, 2021 PP 79-103, ISSN 2707-8035

Ogbenjuwa, L., Egbu, C., \& Robinson, H. (2018). A Strategic Approach to real Estate Financing : Challenges and Opportunities in Real Estate Financing in Nigeria. RICS COBRA Conference 2018. London: London South Bank University.

O'Keeffe, P. (2016). Supply chain management strategies of agricultural corporations: A resource dependency approach. Competition \& Change, 20(4), 255-274.

Omar, S. H. (2015). The relationship between firm size and the relationship between firm size and banks in Kenya.

Onatca, E., Sefika, N., Erbas, U., \& Gokhan, A. (2019). Pecking Order Theory in Determining The Capital Structure: A Panel Data Analysis Of Companies in Turkey. Business and Economists Journal, 10(3),687-698.

Owuor, N. D., Githii, W., \& Mirie, M. (2018). The Relationship Between Macroeconomic Factors and Mortgage Market Growth in Kenya. European Scientific Journal, 14(10),67-82.

Pancak, A. K., \& Miceli, J. T. (2017). Just Compensation for the Taking of Mortgage Loans . Journal of Law and Economics and Policy, 13,143-151.

Pavlov, A. D., Steiner, E., \& Watcher, S. M. (2015). Macroeconomic risk factors and the role of mispriced credit in the returns from international real estate securities. Real Estate Economics, 43(1): 241-270.

Pfeffer, J. (1987). A resource dependence perspective on interorganizational relations, " in Mizruchi, M. S. and Schwartz, M., Intercorporate Relations: The Structural Analysis of Business. Cambridge: Cambridge University Press.

Pfeffer, J. (2005). Developing resource dependence theory: how theory is affected by its Environment. In K. G. Smith, \& M. A. Hitt, Great minds in Management: The Process of Theory Development. New York: Oxford University Press.

Purwohandoko. (2017). The influence of firm's size, growth, and profitability on firm value with capital structure as the Mediator: a study on the agricultural firms listed in the Indonesian Stock Exchange. International Journal of Economics and Finance, Vol. 9, No. 8(103-110).

Revilla, E., Acosta, J., \& Sarkis, J. (2014). Performance evaluation of research joint ventures: an organizational learning perspective. Journal of Economics and Sustainable Development, 3(4), 34-52.

Rousseau, P., \& Watchel, P. (2011). What is happening to the impact of financial deepeneing on economic growth?". Economic Inquiry, 49, 276-288.

Salancik, G. R., \& Pfeffer, J. (1978). The External Control of Organizations. A Resource Dependence Perspective. New York.

Satirenjit, K. J., Shireenjit , K., \& Barry , C. J. (2015). Board characteristics and firm performance: evidence from Malaysian public Listed Firms. Journal of Economics, Business and Management, 3(2),239-243.

Schiele, H., Ellis, S., Ebig, M., Henke, W. J., \& Kull, J. T. (2015). Managing supplier satisfaction: Social capital and resource dependence frameworks. Australasian Marketing Journal (AMJ), 23(2),132-138.

Schindler, P., \& Cooper, D. (2014). Business Research Methods, 12th ed. Boston: McGrawHill/Irwin.

Sekaran, U., \& Bougie, R. (2010). Research Methods for Business: A Skill Building Approach, 5th ed. . West Sussex: John Wiley and Sons Ltd.

Simon, M. K. (2011). Dissertation and scholarly research: recipes for success. Seattle: Dissertation Success, LLC.

Simon, M. K. (2011). Dissertation and Scholarly Research: Recipes for Success. Seattle: Dissertation Success, LLC. 
International Journal of Current Aspects in Finance, Banking and Accounting, Volume 3, Issue 2, 2021 PP 79-103, ISSN 2707-8035

Tsvihum, O. (2014). Economic growth and institutions: mortgage lending in Ukraine. Journal of Finance and Bank Management, 2(3),56-60.

Turkmen, Y., \& Demirel. (2012). Economic factors affecting financial ratios: real estate investments trusts, case on ISE. European Journal of Scientific Research, 69(1):42-51.

UN_HABITAT. (2011). The Impact of the Global Financial Crisis on Housing Finance. . New York: United Nations.

United States Bureau. (2019, October 2). American Housing Survey (AHS). Retrieved from United States Bureau: https://www.census.gov/programs-surveys/ahs.html

Vandana, B., Pramod, K. J., \& Surendra, S. Y. (2016). Testing the pecking order theory of deficit and surplus firms: Indian evidence. nternational Journal of Managerial Finance, 12(3),335-350.

Vuluku, G., \& Gachanja, J. (2014). Supply side aspects of residential housing for low income earners in Kenya. Research in Applied Economics, 6(3), 271.

Wang, Y., Wang, S., Li, G., Zhang, H., \& Li, L. (2017). Identifying the determinants of housing prices in China using spatial regression and the geographical detector technique. Applied Geography, 79(1):26-36.

Whisman, M. A., \& McClelland, G. H. (2005). Designing, testing, and interpreting interactions and moderator effects in family research. Journal of Family Psychology, 19(1),111120.

Wiarda, H. J. (2018). New Directions In Comparative Politics. New York: Routledge.

Wiesner, E. (2017). Evaluation and Development: The Institutional Dimension. New York: Routledge.

Williamson, O. E. (1975). Markets and hierarchies: analysis and antitrust implications: a study in the. New York: The Free Press.

Word Bank Report. (2019). The Kenya economic update: housing-unavailable and unaffordable. New York: World Bank Group(WBG).

World Bank. (2010). Kenya's Informal Settlement. New York: The World Bank Group.

$\mathrm{Xu}$, Xianqing, E., \& Chen, T. (2011). The effect of monetary policy on real estate price growth in China. Pacific Basin Finance Journal, 1(2): 36-51.

Yacine, A. S., \& Dacheng, X. (2018). A Hausman test for the presence of market microstructure noise in high frequency dat. Journal of Econometrics, 209(2),145-157.

Zelia, S., \& Caetano, A. (2015). Trade-Off Theory versus Pecking Order Theory: capital structure decisions in a peripheral region of Portugal. Journal of Business Economics and Management, 16(2),445-466.

This is an open-access peer reviewed article published and distributed under the terms

and conditions of the (c) (i) (8) Creative Commons Attribution 4.0 International License of United States unless otherwise stated. Access, citation and distribution of this article is allowed with full recognition of the authors and the source. Copyright, content ownership and liability for content herein remain with the authors. 